\title{
11. GEOCHEMISTRY OF CENOZOIC ASH LAYERS FROM THE KERGUELEN PLATEAU (LEG 120): A FIRST STEP TOWARD A TEPHROSTRATIGRAPHY OF THE SOUTHERN INDIAN OCEAN 1
}

\author{
W. Morche, ${ }^{2}$ H.-W. Hubberten, ${ }^{2}$ A. Mackensen, ${ }^{2}$ and J. Keller ${ }^{3}$
}

\begin{abstract}
Geochemical investigations were conducted on 10 discrete ash layers and 22 samples of dispersed ash accumulations from Sites 747, 749, and 751 of Ocean Drilling Program (ODP) Leg 120 to the Kerguelen Plateau in the southern Indian Ocean. The chemical data obtained from some 400 single-grain glass analyses allow the characterization of two rock series. The first consists of transitional to alkali basalts; the second, mainly of trachytes with subordinated rhyolites, all reflecting the characteristic magmatological evolution of the Kerguelen Plateau as a hotspot-related volcanism. Chemical correlation with possible source areas indicates that the ashes were most probably erupted from the Kerguelen Islands. The investigated ash layers clearly reflect the Oligocene to Quaternary changes in the composition of the volcanic material recorded from the Kerguelen Islands. In addition to the Kerguelen Islands, Heard Island, Crozet Island, and other sources may have contributed to deposition of the tephras. Pleistocene tephras of "exotic" calc-alkaline composition are most probably derived from enhanced magmatic activity during that time span at the South Sandwich island arc.

When using data obtained from tephras of the ODP Leg 119 Kerguelen sites, several eruptive periods can be correlated through the composition of the deposited ashes. Some of them are widely distributed over the Kerguelen Plateau and are seen as a first step toward a southern Indian Ocean tephrostratigraphy.
\end{abstract}

\section{INTRODUCTION}

The Kerguelen Plateau is situated between $46^{\circ}$ and $64^{\circ} \mathrm{S}$ in the southern Indian Ocean and trends northwest for approximately $2500 \mathrm{~km}$. It is about $500 \mathrm{~km}$ wide and rises $2-4 \mathrm{~km}$ above the adjacent deep-sea basins. The Kerguelen Plateau is the world's largest submarine plateau and can be divided into two distinct domains (Schlich, 1975; Houtz et al., 1977): the Northern Kerguelen Plateau or Kerguelen-Heard Plateau, located between $46^{\circ}$ and $54^{\circ} \mathrm{S}$, and the Southern Kerguelen Plateau.

Five sites were drilled on the Southern Kerguelen Plateau during Leg 120 of the Ocean Drilling Program (ODP): 747, 748, 749, 750, and 751 (Schlich, Wise, et al., 1989; Fig. 1). Particularly for our study of volcanic ash geochemistry, we selected Site 747 from the Central Kerguelen Plateau, where numerous distinct ash layers were encountered. In addition, the only ash layers drilled at Sites 749 and 751 on the Southern Kerguelen Plateau were studied. At Site 747, volcanic ash was encountered, either dispersed within the sediments or as discrete ash layers; this occurrence reflects the influence of numerous volcanic eruptions through time. In contrast, Sites 749 and 751 , located south of Site 747, yielded only one ash layer each and only small amounts of dispersed glass grains. At Sites 748 and 750 no volcanic ash was recorded.

The purpose of this study is to determine the chemical composition of the ash layers. Furthermore, using these data, we discuss the provenance of the volcanic material. Because of the prevailing westerly winds and eastward-flowing ocean surface currents in this region, source areas of the tephras distributed by wind, ocean currents, and ice rafting are most

\footnotetext{
${ }^{1}$ Wise, S. W., Jr., Schlich, R., et al., 1992. Proc. ODP, Sci. Results, 120: College Station, TX (Ocean Drilling Program).

${ }^{2}$ Alfred Wegener Institute for Polar and Marine Research, Columbusstrasse, D-2850 Bremerhaven, Federal Republic of Germany.

${ }^{3}$ Mineralogisch-Petrographisches Institut, Universität Freiburg/Breisgau, Albertstrasse 23b, D-7800 Freiburg, Federal Republic of Germany.
}

likely (but not exclusively) located to the west of the drill sites. During the time interval in which the deposits examined in this study were formed (Oligocene to Quaternary), volcanic activity in the vicinity of the drill sites has been recorded from Kerguelen and Heard islands and Crozet, the last of which was active only in Quaternary time (Girod and Nougier, 1972).

The magmas erupted on the Kerguelen Islands display a wide compositional range characterized by two main rock series: an older transitional to alkali basalt series that probably formed since Eocene time, and a younger trachyphonolitic series (Nougier, 1972a, 1972b; Giret and Lameyre, 1983; Giret et al., 1987; Watkins et al., 1974; Nougier et al., 1983). The volcanic products of Heard Island belong to both an alkali basaltic and a trachytic series, as on the Kerguelen Islands, and are presumed to have formed at least since the late Miocene (Stephenson, 1972; Clarke et al., 1983). The Quaternary volcanic rocks of Crozet Island, in contrast, belong to one basaltic rock suite that shows much less compositional variability (Chevallier et al., 1983; Gunn et al., 1972).

Additional information is available from volcanic ash layers that occur in Leg 119 Sites 736 and 737, which are located closer to the assumed eruption centers (Morche et al., 1991). With the help of the geochemical data available from this study, we will try to correlate characteristic ashes between the Leg 119 and 120 sites.

\section{MATERIAL AND METHODS}

Ten discrete ash layers were investigated from Holes 747A, $747 \mathrm{~B}, 749 \mathrm{~B}$, and $751 \mathrm{~A}$. In addition, 22 accumulations of dispersed ashes from Holes 747A and 747B were studied to obtain more information about volcanic activity in the Kerguelen Plateau area from the Oligocene to the present (Tables 1 and 2).

Site $747\left(54^{\circ} 48.68 \mathrm{~S}, 76^{\circ} 47.64 \mathrm{E} ; 1697-\mathrm{m}\right.$ water depth) penetrated to a total depth of $350 \mathrm{~m}$ below sea floor (mbsf). The oldest sediments recovered have a Santonian age (Schlich, Wise, et al., 1989). Volcanic ash and pumice accumulations are restricted to the uppermost $170 \mathrm{~m}$ of Holes $747 \mathrm{~A}$ and 747B 


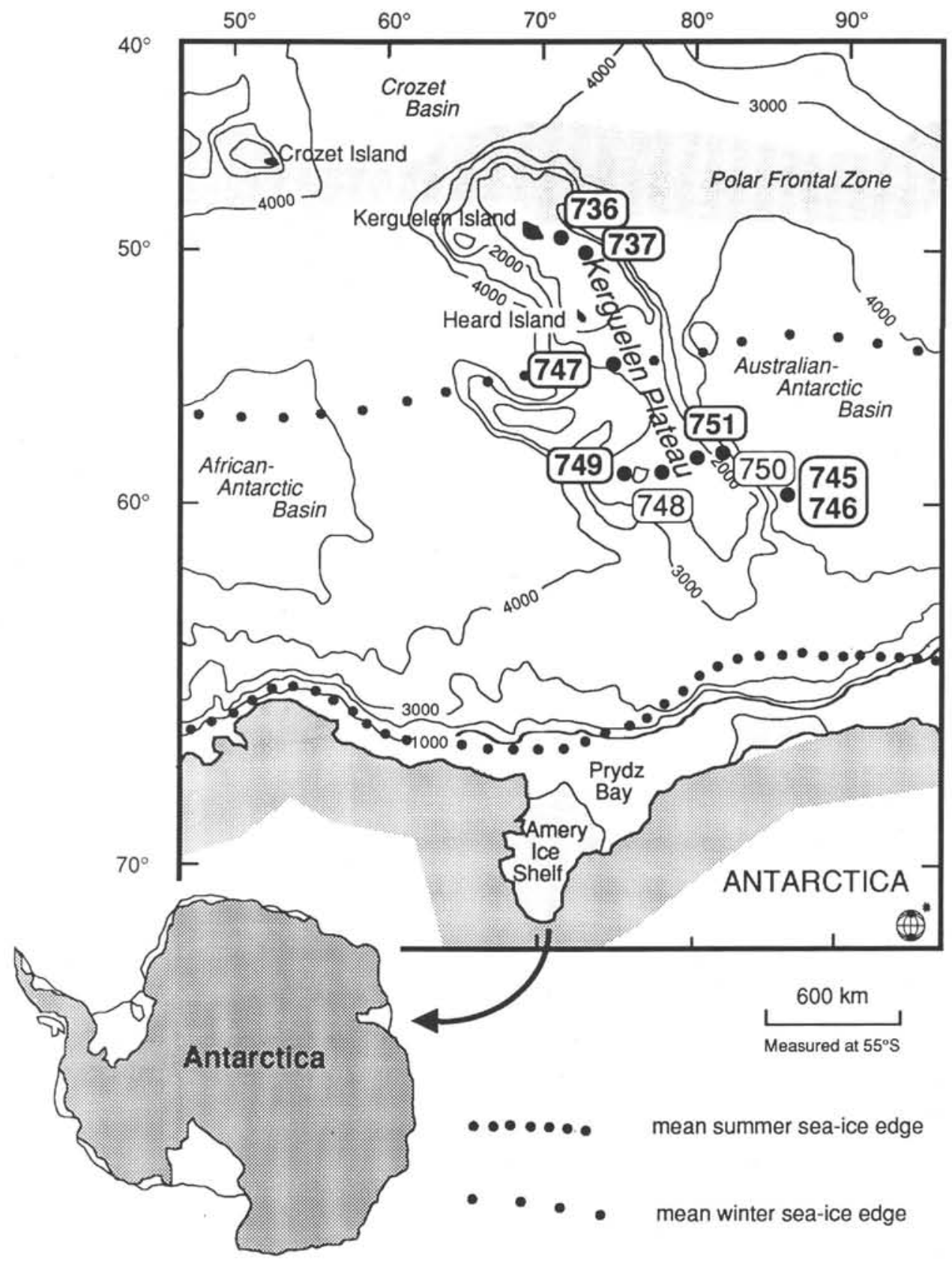

Figure 1. Location of Leg 120 drill sites, as well as Sites 736, 737, 745, and 746 drilled during Leg 119 in the southern Indian Ocean. The bathymetry (in meters) is from GEBCO (Hayes and Vogel, 1981; Fisher et al., 1982). The position of the Polar Frontal Zone has been placed according to Whitworth (1988); the position of sea-ice coverage has been diagrammed according to Dietrich and Ulrich (1968).

and range from early Oligocene to Pliocene age. We investigated all seven discrete layers recovered from Site 747 (Table 1 and Fig. 2).

Sites $749\left(58^{\circ} 43.03^{\prime} \mathrm{S}, 76^{\circ} 24.45^{\prime} \mathrm{E} ; 1069.5-\mathrm{m}\right.$ water depth; $252-\mathrm{m}$ penetration) and $751\left(57^{\circ} 43.56^{\prime} \mathrm{S}, 79^{\circ} 48.89^{\prime} \mathrm{E} ; 1634-\mathrm{m}\right.$ water depth; $170-\mathrm{m}$ penetration) recovered lower Eocene to Quaternary sediments (Barron, Larsen, et al., 1989). Only one discrete ash layer was obtained from Hole 749B, and one from Hole 751.

All tephra samples were dried at $50^{\circ} \mathrm{C}$. Carbonate was removed by adding $10 \%$ hydrochloric acid. The carbonate- free residue was rinsed with distilled water and dried. The samples were then sieved to obtain $<63,63-200$, and $>200-\mu \mathrm{m}$ fractions. Only the $63-200-\mu \mathrm{m}$ fraction was used for further study. The samples were first described by means of a petrographic microscope. Textural features were then documented with the help of a scanning electron microscope (SEM). The glass shards were separated using a heavy liquid and a Frantz Isodynamic magnetic separator. Polished grain mounts were prepared for microprobe analyses and petrographic studies. The geochemical analyses were performed with an energy-dispersive KEVEX equipment (EDX) at- 
Table 1. Samples from discrete tephra layers, Leg 120.

\begin{tabular}{cll}
\hline $\begin{array}{c}\text { Core, section, } \\
\text { interval (cm) }\end{array}$ & $\begin{array}{c}\text { AWI } \\
\text { no. }\end{array}$ & \multicolumn{1}{c}{ Age } \\
\hline $\begin{array}{c}120-747 \mathrm{~A}- \\
\text { 3H-1, } 28-30\end{array}$ & 22 & late Pliocene \\
$3 \mathrm{H}-2,122-124$ & 23 & late Pliocene \\
$3 \mathrm{H}-6,59-61$ & $87-1$ & $\begin{array}{l}\text { early Pliocene } \\
\text { middle Miocene }\end{array}$ \\
$7 \mathrm{H}-3,137-139$ & $86-2$ & middle Miocene \\
$7 \mathrm{H}-3-\mathrm{CC}$ & 48 & late Oligocene \\
$16 \mathrm{H}-5,31-32$ & 25 & late Oligocene \\
$16 \mathrm{H}-6,5-7$ & 26 & late Pliocene \\
$120-747 \mathrm{~B}-$ & 24 & \\
$3 \mathrm{H}-4,65-67$ & & Quaternary \\
$120-749 \mathrm{~B}-$ & $87-2$ & \\
$2 \mathrm{H}-2,0-2$ & & \\
$120-751 \mathrm{~A}-$ & 27 & late Pliocene \\
$4 \mathrm{H}-6,86-88$ & & \\
\hline
\end{tabular}

Notes: Ocean Drilling Program (ODP) sample numbers and corresponding Alfred Wegener Institute (AWI) laboratory numbers are given.

tached to an SEM at Freiburg University. To avoid uncontrolled loss of $\mathrm{Na}_{2} \mathrm{O}$, glass particles were analyzed under a defocused electron beam of $10 \times 10 \mathrm{~m}$ minimum (accelerating voltage $=15 \mathrm{kV}$, beam current $=\sim 5 \mathrm{nA}$, counting time $=100$ s). Matrix corrections and calibration with mineral and glass standards from the Smithsonian Institution were made (Jarosewich et al., 1980). Selected analyses of used standards are given in Table 3 for comparison. To obtain additional information about volcanic activity, the sand-size fraction $(>63 \mathrm{~m})$ of the carbonate- and opal-free nonbiogenic material from Holes 747A and 747B was studied with respect to the content of dispersed ash. Twenty-two samples containing $>30 \%$ glass shards were selected for geochemical analysis.

\section{RESULTS}

The most important results of our study were obtained from the analyses of the discrete tephra layers from Holes $747 \mathrm{~A}$ and 747B. These ash layers are Pliocene, middle Miocene, and late Oligocene in age, and display either alkali basaltic or trachytic composition. The basaltic ash layer recovered at Hole 749B is of Quaternary age, and the trachytic ash from Hole 751A occurs in late Pliocene sediments. No ash layers were recovered from Sites 748 and 750 on the Southern Kerguelen Plateau, nor did the nonbiogenic $>63-\mathrm{m}$ fraction of the samples from these sites contain significant amounts of volcanic glass, thus showing limits of distribution of tephra toward higher southern latitudes.

Most of the glass shards examined are dark to pale brown, although some samples consist of populations characterized by colorless glass. Glass textures range from dense, poorly vesicular, blocky shards to highly vesicular particles with an elongated, fibrous habit. Tiny mineral inclusions, such as $\mathrm{Fe}-\mathrm{Ti}$ oxides and pyroxenes, are common. The mineral assemblages within the discrete ash layers are all thought to be phenocrysts (euhedral crystals, adhering glass). The compositional difference between the glasses is also reflected in specific mineral assemblages. The trachytic tephras are characterized by the occurrence of $\mathrm{Fe}-\mathrm{Ti}$ oxides, aegirine-augite, plagioclase, alkali feldspar, and apatite. In addition, hedenbergite, biotite, and augite occur in some of these tephras. The tephras that display a transitional to alkali basaltic composition lack alkali pyroxenes and alkali feldspars. Plagioclase, augite, and, in some cases, olivine are the only phenocrysts.

The mean values of chemical data of about 135 analyses of individual glass shards from the Leg 120 discrete tephra layers are presented in Table 4 . The complete data set, including the composition of the dispersed ashes, is listed in the Appendix (on microfiche in back pocket). The geochemistry of the tephras shows a large variation in most of the major elements, not only between, but also within different layers. Two distinctively different compositional groups can be recognized in the plot of total alkalis vs. silica (Fig. 3A):

1. The first group comprises ashes of trachytic composition and is restricted almost exclusively to the Miocene, Pliocene, and Pleistocene ashes of Holes 747A, 747B, and 751A. Most of them plot in a narrow field with silica contents from $60 \%$ to $69 \%$ and total alkali contents between $11 \%$ and $14 \%$. Ash layer 87-1 consists of two glass populations: one typical for this trachytic group, and another with less silica and alkalis (trachyandesitic).

2 . The second group is mainly represented by the Oligocene tephras that display transitional to alkali basaltic compositions. Nevertheless, both Oligocene tephra layers (25 and 26) consist of two glass populations, one of basaltic and one of trachytic to rhyolitic composition. Thus, they represent a nearly complete fractionation series, saturated with respect to silica. Only one younger ash layer, the Quaternary tephra from Hole 749B (87-2), falls within the same basaltic group.

The dispersed tephras in general show the same compositional trends as the discrete tephra layers (Fig. 3B). Additional glasses of trachyandesitic composition occur during Miocene (154-2 and 155-1), Pliocene (153 and 154-2), and Pleistocene (149-1 and 149-2) time. Furthermore, tephras of low-K calcalkaline compositions are found in Quaternary sediments (Samples 149-1, 149-2, 159-1, etc.; see Table 5). Their "exotic" composition in the framework of a hotspot-related magmatism corresponds to island-arc activity. Figure 4 shows the almost complete overlap in the $\mathrm{K}_{2} \mathrm{O}-\mathrm{SiO}_{2}$ diagram with compositions of rocks from the South Sandwich Islands.

\section{DISCUSSION}

In an earlier paper, Morche et al. (1991) concluded that tephras from Sites 736 and 737 (Leg 119) were dominantly derived from the Kerguelen Islands. Site 736 is located about $70 \mathrm{~km}$ east, and Site 737 about $150 \mathrm{~km}$ southeast of the Kerguelen Islands (Fig. 1). Site 747 is located more or less in the same direction with respect to the Kerguelen Islands, however, the distance is much greater (about $900 \mathrm{~km}$ ). Nevertheless, the Kerguelen Islands should be considered the most likely source for the tephras.

The geochemical variations of the two ash series encountered within the sediments of Site 747 show that both represent an almost complete compositional suite. The composition of the analyzed glass shards may be compared with published analyses of rocks from the Kerguelen Islands (Giret and Lameyre, 1983; Morche et al., 1991). The basaltic and trachytic rock series almost completely overlap and, therefore, provide a strong argument for a Kerguelen Islands provenance. The subdivision of the tephras in the Oligocene basaltic (and subordinated trachytic to rhyolitic) group and a younger trachytic group should also be reflected in the eruptive sequence of the Kerguelen Islands if this area was the eruption center. On the Kerguelen Islands, volcanic activity in late Oligocene to early Miocene time was dominated by the eruption of products of transitional to alkali basalt composition; the only dated early rhyolitic formation yielded an age of 26-30 Ma (Nougier, 1972a; Watkins et al., 1974; Giret et al., 1987). This coincides precisely with the ash composition found in the Oligocene section of Holes 747A and 747B (25 and 26), as well as with the Oligocene tephras encountered 
Table 2. Samples of dispersed tephra and their relative concentrations, Leg 120.

\begin{tabular}{|c|c|c|c|c|}
\hline $\begin{array}{l}\text { Core, section, } \\
\text { interval }(\mathrm{cm})\end{array}$ & Abundance & Color & $\begin{array}{l}\text { AWI } \\
\text { no. }\end{array}$ & Age \\
\hline \multicolumn{5}{|l|}{$120-747 \mathrm{~A}-$} \\
\hline $1 \mathrm{H}-2,108-112$ & + & D & & \\
\hline $1 \mathrm{H}-2,144-148$ & + & D & $149-1$ & Pleistocene \\
\hline $1 \mathrm{H}-3,0-4$ & + & D L & & \\
\hline $1 \mathrm{H}-3,36-40$ & + & D L & $149-2$ & Pleistocene \\
\hline $1 \mathrm{H}-3,72-76$ & + & D L & & \\
\hline $1 \mathrm{H}-4,72-76$ & + & D & & \\
\hline $1 \mathrm{H}-4,108-112$ & + & $\mathrm{D}$ & & \\
\hline $1 \mathrm{H}-4,142-146$ & + & D & & \\
\hline $1 \mathrm{H}-5,0-4$ & + & D & & \\
\hline $1 \mathrm{H}-5,36-40$ & ++ & D L & & \\
\hline $1 \mathrm{H}-5,72-76$ & ++ & D L & $148-1$ & Pleistocene \\
\hline $1 \mathrm{H}-5,141-145$ & + & D L & & \\
\hline $1 \mathrm{H}-6,2-6$ & + & D L & & \\
\hline $1 \mathrm{H}-6,36-40$ & + & D L & & \\
\hline $2 \mathrm{H}-1,0-4$ & + & L & & \\
\hline $2 \mathrm{H}-1,36-40$ & + & $\mathrm{L}$ & & \\
\hline $2 \mathrm{H}-1,72-76$ & + & $\mathrm{L}$ & & \\
\hline $2 \mathrm{H}-1,108-112$ & + & L & & \\
\hline $2 \mathrm{H}-1,144-148$ & + & $\mathrm{L}$ & & \\
\hline $2 \mathrm{H}-2,0-4$ & ++ & $\mathrm{L}$ & $148-2$ & Pleistocene \\
\hline $2 \mathrm{H}-2,36-40$ & + & $\mathrm{L}$ & & \\
\hline $2 \mathrm{H}-5,36-40$ & + & D L & & \\
\hline $2 \mathrm{H}-5,72-76$ & + & D L & & \\
\hline $2 \mathrm{H}-6,0-4$ & + & D L & & \\
\hline $2 \mathrm{H}-6,36-40$ & + & D L & & \\
\hline $2 \mathrm{H}-6,72-76$ & + & D L & & \\
\hline $2 \mathrm{H}-6,108-112$ & + & D L & & \\
\hline $2 \mathrm{H}-6,144-148$ & ++ & D L & & \\
\hline $2 \mathrm{H}-7,0-4$ & ++ & D L & & \\
\hline $2 \mathrm{H}-7,36-37$ & ++++ & D L & $150-1$ & late Pliocene \\
\hline $2 \mathrm{H}-7,72-76$ & ++ & L & & \\
\hline $2 \mathrm{H}-7-\mathrm{CC}$ & +++ & L & & \\
\hline $3 \mathrm{H}-1,0-4$ & ++++ & D L & & \\
\hline $3 \mathrm{H}-1,36-40$ & ++++ & D L & & \\
\hline $3 \mathrm{H}-1,72-76$ & + & D L & & \\
\hline $3 \mathrm{H}-1,108-112$ & +++ & D L & & \\
\hline $3 \mathrm{H}-1,144-148$ & + & $\mathrm{L}$ & & \\
\hline $3 \mathrm{H}-2,0-4$ & + & L & & \\
\hline $3 \mathrm{H}-2,72-76$ & ++++ & D L & & \\
\hline $3 \mathrm{H}-2,108-112$ & ++++ & D L & & \\
\hline $3 \mathrm{H}-2,144-148$ & +++ & D L & & \\
\hline $3 \mathrm{H}-3,0-4$ & +++ & $D L$ & & \\
\hline $3 \mathrm{H}-3,36-42$ & ++++ & D L & & \\
\hline $3 \mathrm{H}-3,72-76$ & ++++ & D L & & \\
\hline $3 \mathrm{H}-3,108-112$ & +++ & L & $150-2$ & late Pliocene \\
\hline $3 \mathrm{H}-3,144-148$ & ++ & L & & \\
\hline $3 \mathrm{H}-4,0-4$ & ++ & $\mathrm{L}$ & & \\
\hline $3 \mathrm{H}-4,36-40$ & +++ & D L & & \\
\hline $3 \mathrm{H}-4,72-76$ & +++ & $\overline{\mathrm{D}} \mathrm{L}$ & & \\
\hline $3 \mathrm{H}-4,108-112$ & +++ & D L & & \\
\hline $3 \mathrm{H}-5,0-4$ & +++ & D L & & \\
\hline $3 \mathrm{H}-5,36-40$ & +++ & D L & & \\
\hline $3 \mathrm{H}-5,72-76$ & +++ & D L & & \\
\hline $3 \mathrm{H}-5,108-112$ & +++ & D L & & \\
\hline $3 \mathrm{H}-5,144-148$ & $+++t$ & D L & & \\
\hline $3 \mathrm{H}-6,0-4$ & ++++ & D L & 151 & early Pliocene \\
\hline $3 \mathrm{H}-6,36-40$ & ++++ & $\bar{D} \mathrm{~L}$ & & \\
\hline $4 \mathrm{H}-1,0-4$ & ++ & L & & \\
\hline $4 \mathrm{H}-1,36-40$ & +++ & L & & \\
\hline $4 \mathrm{H}-1,72-76$ & +++ & L & & \\
\hline $4 \mathrm{H}-1,108-112$ & +++ & $\mathrm{L}$ & & \\
\hline $4 \mathrm{H}-1,144-148$ & +++ & $\mathrm{L}$ & & \\
\hline $4 \mathrm{H}-2,0-4$ & +++ & L & $152-1$ & early Pliocene \\
\hline $4 \mathrm{H}-2,36-40$ & +++ & $\mathrm{L}$ & & \\
\hline $4 \mathrm{H}-2,72-76$ & ++++ & D L & & \\
\hline $4 \mathrm{H}-2,108-112$ & ++++ & D L & 153 & early Pliocene \\
\hline $4 \mathrm{H}-2,144-148$ & +++ & D L & & \\
\hline $4 \mathrm{H}-3,0-4$ & +++ & D L & & \\
\hline $4 \mathrm{H}-3,36-40$ & ++ & D L & & \\
\hline $4 \mathrm{H}-3,72-76$ & ++ & D L & & \\
\hline $4 \mathrm{H}-3,108-112$ & ++ & D L & & \\
\hline $4 \mathrm{H}-4,0-4$ & +++ & D L & & \\
\hline $4 \mathrm{H}-4,36-40$ & ++++ & D L & & \\
\hline $4 \mathrm{H}-4,72-76$ & ++++ & D L & $152-2$ & early Pliocene \\
\hline $4 \mathrm{H}-4,108-112$ & ++++ & D L & & \\
\hline
\end{tabular}

Table 2 (continued).

\begin{tabular}{|c|c|c|c|c|}
\hline $\begin{array}{l}\text { Core, section, } \\
\text { interval }(\mathrm{cm})\end{array}$ & Abundance & Color & $\begin{array}{l}\text { AWI } \\
\text { no. }\end{array}$ & Age \\
\hline $4 \mathrm{H}-4,144-148$ & $++t+$ & D L & & \\
\hline $4 \mathrm{H}-5,0-4$ & $+++t$ & D L & & \\
\hline $4 \mathrm{H}-5,36-40$ & +++ & D L & & \\
\hline $4 \mathrm{H}-5,72-76$ & +++ & D L & & \\
\hline $4 \mathrm{H}-5,108-112$ & +++ & D L & $154-1$ & early Pliocene \\
\hline $4 \mathrm{H}-5,144-148$ & ++ & D L & & \\
\hline $4 \mathrm{H}-6,0-4$ & ++ & D L & & \\
\hline $4 \mathrm{H}-6,36-40$ & ++ & D L & & \\
\hline $4 \mathrm{H}-6,72-76$ & ++ & D L & & \\
\hline $4 \mathrm{H}-6,108-112$ & ++ & D L & & \\
\hline $4 \mathrm{H}-6,144-144$ & ++ & D L & & \\
\hline $4 \mathrm{H}-7,0-4$ & ++ & D L & & \\
\hline $4 \mathrm{H}-7-\mathrm{CC}$ & ++ & D L & & \\
\hline $4 \mathrm{H}-7,36-40$ & ++ & D L & & \\
\hline $4 \mathrm{H}-7,72-76$ & ++ & D L & $154-2$ & late Miocene \\
\hline $5 \mathrm{H}-4,72-76$ & ++ & D L & & \\
\hline $5 \mathrm{H}-6,72-76$ & ++ & D L & $155-1$ & late Miocene \\
\hline $5 \mathrm{H}-6-\mathrm{CC}$ & +++ & D L & & \\
\hline $6 \mathrm{H}-2,72-76$ & + & L & $155-2$ & late Miocene \\
\hline $6 \mathrm{H}-4,72-76$ & + & $\mathrm{L}$ & $156-1$ & late Miocene \\
\hline $16 \mathrm{H}-5,72-76$ & +++ & D L & $156-2$ & late Oligocene \\
\hline $16 \mathrm{H}-\mathrm{CC}$ & ++ & D L & & \\
\hline $17 X-2,72-76$ & ++ & D & $157-1$ & late Oligocene \\
\hline $17 X-5,72-76$ & ++ & D & $157-2$ & late Oligocene \\
\hline $17 \mathrm{X}-\mathrm{CC}$ & ++ & D & & \\
\hline $18 \times-2,72-76$ & + & D & $158-1$ & early Oligocene \\
\hline $18 \times-2,72-76$ & + & D & $158-1$ & early Oligocene \\
\hline $18 \mathrm{X}-\mathrm{CC}$ & + & D & & \\
\hline \multicolumn{5}{|l|}{$120-747 \mathrm{~B}-$} \\
\hline $1 \mathrm{H}-2,0-4$ & + & D & & \\
\hline $1 \mathrm{H}-2,36-40$ & + & $\mathrm{D}$ & $158-2$ & Pleistocene \\
\hline $2 \mathrm{H}-2,108-112$ & + & D & $159-1$ & Pleistocene \\
\hline $2 \mathrm{H}-3,144-148$ & ++ & L & $159-2$ & Pleistocene \\
\hline
\end{tabular}

Notes: $t=1 \%-5 \%,++=5 \%-20 \%,+++=20 \%-50 \%,++++=$ $>50 \%$ ). $\mathrm{D}=$ brown to dark brown, $\mathrm{L}=$ colorless to light yellow.

within Holes 737A and 737B of Leg 119 (Morche et al., 1991). In contrast to the Oligocene ash layers analyzed from Site 737, where all glasses are exclusively of basaltic composition, the two Site 747 ashes (25 and 26) show more or less bimodal compositions ranging from basalts to trachytes and rhyolites. In the case of Sample 26, a continuous tapping of a zoned magma chamber is suggested.

Most of the Miocene, Pliocene, and Pleistocene tephras of Sites 747 (Fig. 2) and 751 belong to the trachytic to rhyolitic series, reflecting enhanced explosive volcanic activity. Because volcanic rocks displaying trachytic composition have erupted at the Kerguelen Islands predominantly during the Miocene to Quaternary time span (Nougier 1972a, 1972b; Giret et al., 1987), we suggest that the Kerguelen Islands have to be regarded as the source of the younger ashes found at Sites 747 and 751 .

Other possible sources of the tephras could be Heard Island, about $450 \mathrm{~km}$ southeast of the Kerguelen Islands, and, less likely, Crozet Island in the far northwest. Heard Island, which is located much closer to Site 747 than to Site 737 , shows many similarities with Kerguelen in terms of the composition of the magmatic rock series and evolution during time (Stephenson, 1972; Clarke et al., 1983). Crozet Island, on the other hand, forms a single Quaternary alkali-basalt petrographic province (Gunn et al., 1972; Chevallier et al., 1983) and cannot be the source of the Oligocene basaltic or Quaternary trachytic tephras found in sediments at Sites 747 and 751.

We conclude, therefore, that almost all of the discrete tephra layers studied were erupted from the Kerguelen Islands. Heard Island has to be considered as another important source of volcanic ash. Transport of additional tephra to the site of deposition by ice rafting is also possible, because all of 


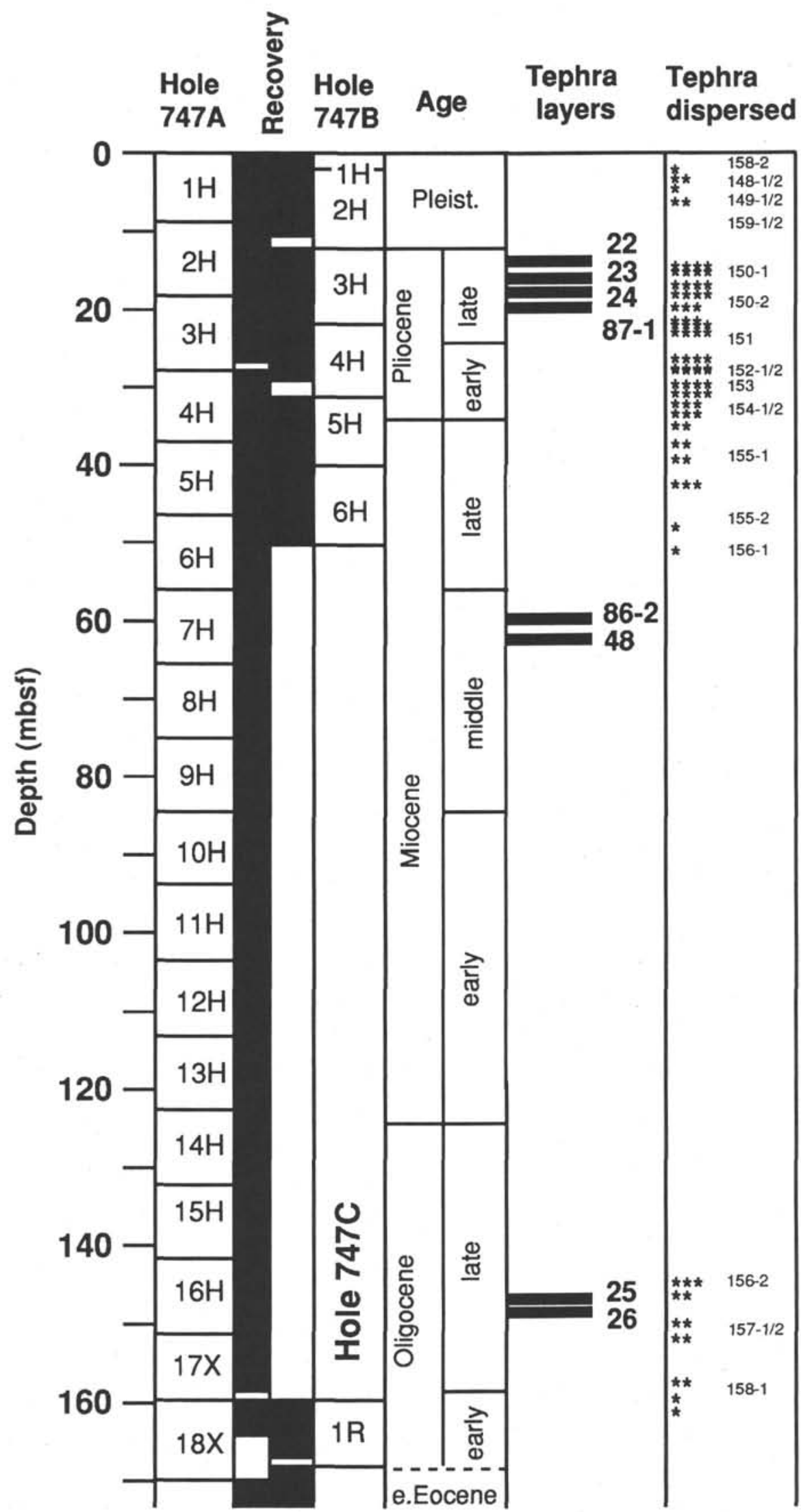

Figure 2. Schematic stratigraphic column, Site 747. The position of the discrete tephras investigated (solid lines) as well as their Alfred-Wegener-Institute (AWI) laboratory numbers are shown. Accumulations and relative abundance of dispersed tephras are marked with an asterisk. 
Table 3. Analytical results obtained by EDX at Freiburg University on Smithsonian Institution reference glass and mineral standards.

\begin{tabular}{lllrrrrrrrrr}
\hline USNM & & $(\%)$ & $\mathrm{SiO}_{2}$ & $\mathrm{TiO}_{2}$ & $\mathrm{Al}_{2} \mathrm{O}_{3}$ & $\mathrm{FeO}$ & $\mathrm{MnO}$ & $\mathrm{MgO}$ & $\mathrm{CaO}$ & $\mathrm{K}_{2} \mathrm{O}$ & $\mathrm{Na}_{2} \mathrm{O}$ \\
\hline 111240 & Smithsonian & (mean) & 51.11 & 1.86 & 14.14 & 11.91 & 0.22 & 6.75 & 11.18 & 0.19 & 2.64 \\
Basalt & Freiburg & (mean) & 50.86 & 1.86 & 14.21 & 12.11 & 0.22 & 6.69 & 11.21 & 0.18 & 2.75 \\
glass & & (SD) & 0.15 & 0.04 & 0.02 & 0.15 & 0.03 & 0.07 & 0.08 & 0.01 & 0.12 \\
113498 & Smithsonian & (mean) & 51.68 & 4.12 & 12.67 & 13.40 & 0.00 & 5.15 & 9.44 & 0.83 & 2.70 \\
Basalt & Freiburg & (mean) & 51.60 & 3.91 & 12.70 & 13.70 & 0.27 & 4.76 & 9.17 & 0.90 & 2.96 \\
glass & & (SD) & 0.07 & 0.07 & 0.16 & 0.12 & 0.08 & 0.15 & 0.14 & 0.03 & 0.15 \\
113716 & Smithsonian & (mean) & 51.84 & 1.31 & 15.49 & 9.12 & 0.00 & 8.26 & 11.39 & 0.09 & 2.49 \\
Basalt & Freiburg & (mean) & 51.97 & 1.32 & 15.42 & 9.15 & 0.15 & 7.82 & 11.32 & 0.15 & 2.77 \\
glass & & (SD) & 0.42 & 0.03 & 0.08 & 0.15 & 0.11 & 0.12 & 0.10 & 0.03 & 0.11 \\
72854 & Smithsonian & (mean) & 77.19 & 0.12 & 12.14 & 1.24 & 0.03 & 0.09 & 0.50 & 4.92 & 3.77 \\
Rhyolite & Freiburg & (mean) & 77.51 & 0.04 & 12.19 & 1.06 & 0.00 & 0.00 & 0.51 & 5.07 & 3.62 \\
glass & & (SD) & 0.20 & 0.08 & 0.15 & 0.09 & 0.00 & 0.00 & 0.03 & 0.07 & 0.05 \\
115900 & Smithsonian & (mean) & 51.21 & 0.05 & 30.89 & 0.46 & 0.00 & 0.14 & 13.63 & 0.18 & 3.45 \\
Plagioclase & Freiburg & (mean) & 51.51 & 0.00 & 30.77 & 0.36 & 0.04 & 0.00 & 13.36 & 0.14 & 3.69 \\
& & (SD) & 0.07 & 0.00 & 0.10 & 0.04 & 0.08 & 0.00 & 0.25 & 0.02 & 0.14 \\
\hline
\end{tabular}

Notes: Means of the Freiburg analyses are based on 4-8 single analyses. SD $=$ standard deviation. The reference analyses given (numbers = USNM standards) are taken from Jarosewich et al. (1980).

the drill sites are situated in an area characterized by a high frequency of drifting icebergs (Barron, Larsen, et al., 1989). Sea-ice rafting may also have been an important process of transport for the volcanic ashes, because the sites are situated far south of the mean winter sea-ice edge (Fig. 1). This seems to be the case especially for the low-K calcalkaline Pleistocene tephras, which can be geochemically correlated with the island-arc activity of the South Sandwich Islands.

\section{TEPHROCHRONOLOGY}

In this section, we will discuss our geochemical results to correlate ash layers between ODP sites from Legs 119 and 120 on the Kerguelen Plateau. Data and results from Morche et al. (1991) are used for correlation. A preliminary geochronological synopsis, comparing all the tephra layers studied from the Kerguelen Plateau (Legs 119 and 120) with the rock series of the Kerguelen Islands, is shown in Figure 5. As discussed

Table 4. Mean values of chemical data from the discrete ash layers studied, Leg 120 .

\begin{tabular}{|c|c|c|c|c|c|c|c|c|c|c|c|}
\hline $\begin{array}{c}\text { AWI } \\
\text { no. }\end{array}$ & (\%) & $\mathrm{P}_{2} \mathrm{O}_{5}$ & $\mathrm{SiO}_{2}$ & $\mathrm{TiO}_{2}$ & $\mathrm{Al}_{2} \mathrm{O}_{3}$ & $\mathrm{FeO}$ & $\mathrm{MnO}$ & $\mathrm{MgO}$ & $\mathrm{CaO}$ & $\mathrm{K}_{2} \mathrm{O}$ & $\mathrm{Na}_{2} \mathrm{O}$ \\
\hline 22 & Mean & 0.00 & 66.05 & 0.54 & 14.62 & 5.50 & 0.22 & 0.00 & 1.16 & 5.58 & 6.26 \\
\hline$N=9$ & SD & 0.00 & 1.04 & 0.13 & 0.65 & 0.12 & 0.14 & .00 & 0.24 & 0.28 & 0.28 \\
\hline 23 & Mean & 0.00 & 62.43 & 0.48 & 17.85 & 4.06 & 0.11 & 0.00 & 1.16 & 6.08 & 7.67 \\
\hline$N=9$ & SD & 0.00 & 0.53 & 0.12 & 0.17 & 0.25 & 0.13 & 0.00 & 0.14 & 0.25 & 0.55 \\
\hline 24 & Mean & 0.00 & 65.03 & 0.72 & 15.29 & 5.48 & 0.17 & 0.00 & 1.48 & 5.79 & 5.97 \\
\hline$N=14$ & SD & 0.00 & 1.56 & 0.3 & 0.81 & 0.10 & 0.12 & 0.00 & 0.48 & 0.43 & 0.30 \\
\hline $25(\mathrm{~A})$ & Mean & 0.53 & 53.93 & 2.94 & 14.76 & 12.92 & 0.11 & 2.87 & 7.53 & 2.04 & 2.90 \\
\hline$N=3$ & SD & 0.2 & 6.02 & 1.1 & 0.71 & 2.78 & 0.20 & 1.57 & 2.84 & 1.64 & 1.17 \\
\hline 5 (B) & Mean & 0.00 & 69.13 & 0.4 & 12.68 & 6.14 & 0.14 & 0.00 & 1.35 & 5.24 & 4.71 \\
\hline$N=1$ & SD & 0.0 & 2.80 & 0.1 & 1.42 & 1.15 & 0.14 & 0.00 & 0.67 & 0.31 & 0.73 \\
\hline 26 & Mean & 0.1 & 59.10 & 1.9 & 14.5 & 9.85 & 0.21 & 1.73 & 5.59 & 3.01 & 4.03 \\
\hline $\begin{array}{l}N=24 \\
\text { (total) }\end{array}$ & SD & 0.2 & 6.92 & 1.1 & 0.29 & 3.46 & 0.11 & 1.69 & 3.03 & 1.57 & 0.80 \\
\hline 26 (B) & fean & 0.00 & 67.67 & 0 & 14.53 & 5.39 & 0.10 & 0.00 & 2.00 & 5.02 & 4.68 \\
\hline$N=8$ & SD & & 1.46 & & 0. & 0.91 & 0.12 & 0 & .48 & 0.66 & 0.49 \\
\hline 27 & Uean & 0.1 & 67.51 & 0. & 13.2 & 5.89 & 0.22 & 0 & .81 & 5.23 & 6.39 \\
\hline$N=10$ & SD & & 104 & 0.1 & 0.95 & 0.33 & 0.10 & 0 & 0.14 & 0.20 & 0.24 \\
\hline 48 & Mean & 0.17 & 63.35 & 0. & 17.16 & 4.42 & 1.53 & .00 & .07 & 6.44 & 6.26 \\
\hline$N=$ & SD & 0.09 & 3.87 & 0 & 2.22 & 0.35 & 0.47 & 0 & 0.10 & 0.63 & 0.63 \\
\hline $86-2$ & Mean & 0. & 64.45 & & 16.8 & 4.60 & 0.04 & 0 & 1.29 & 6.23 & 5.84 \\
\hline$N=9$ & SD & & 10 & & 0. & 0. & 0.09 & 0 & 0.18 & 0.33 & 0.14 \\
\hline $87-11$ & Mean & 0. & 55.44 & 2. & 17.84 & 8.09 & 0.08 & 2 & 5.79 & 4.50 & 4.56 \\
\hline 6 & SI & & 1.7 & & 0. & 0.43 & 0.09 & 3 & 0.38 & 0.51 & 0.32 \\
\hline $87-11 \mathrm{E}$ & Mean & 0. & 60.4 & & 19.2 & 4.48 & 0.02 & 0 & 1.74 & .58 & 6.64 \\
\hline & s & & & & 1. & & 0.07 & & 0.29 & 49 & 0.60 \\
\hline $87-21$ & Mean & 0. & 50.7 & & 14.6 & 13.91 & 0.14 & 2 & 9.20 & .26 & 2.64 \\
\hline & 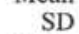 & & & & & 1.75 & & & 0.80 & 0.38 & 0.45 \\
\hline $87-2(1$ & Mean & 0.0 & 60.3 & 0. & 19.0 & 4.77 & 0.00 & 0.00 & 1.71 & 6.55 & 6.68 \\
\hline & $\mathrm{S}$ & 0. & 0. & 0. & 0. & 0. & 0.00 & 0.00 & 0.30 & 0.13 & 0.78 \\
\hline $87-21 C$ & Mean & 0.00 & 68.58 & 0.26 & 14.86 & 3.93 & 0.00 & 0.00 & 0.82 & 5.60 & 5.54 \\
\hline
\end{tabular}

Notes: Ash layers in which different geochemical groups of glass shards can be discriminated are indicated as (A), (B), and (C), respectively. $N=$ number of individual glass shards analyzed from a single ash sample. $\mathrm{SD}=$ standard deviation. 
above, all of the discrete tephra layers encountered in the Oligocene to Quaternary sediments from the Kerguelen Plateau may have been derived from the Kerguelen Island volcanic rock series as basaltic volcanism occurred over the entire time span and trachytic magmatic activity took place since the late Oligocene.

An analogue to the numerous Quaternary trachytic tephras from Site 736 is found in the tephras of Site 747A (149-1, 149-2, 159-1, and 159-2) and in a more distal position at Site 749 (87-2). The latter shows bimodal composition with an additional basaltic part, which can also be found in Site 747A (158-2). The oldest Quaternary ash of Site 736 (77) shows a bimodal glass composition with one trachytic group that corresponds to the aforementioned tephras and can therefore be assumed to have formed through the same eruptive event from either the Kerguelen or Heard islands. The glasses of low-K calc-alkaline composition from Layer 77 correspond with Pleistocene glasses from Site 747 (149-1, 149-2, 158-2, and 159-1; Table 5). These tephras most probably were derived from the South Sandwich Islands. The distance of about $6500 \mathrm{~km}$ indicates sea-ice rafting as an important mechanism of transport. Furthermore, these data can be compared with analyses of Quaternary glasses from ODP Leg 114 (Table 5). At Site 701 the thick proximal facies of tephras from the South Sandwich Islands have been recognized as much as several centimeters thick (Hubberten et al., 1991).

All of the Pliocene tephras found in Sites 737, 747, 751, and 745 display the same trachytic composition and may be correlated. They are probably the result of a period of major explosive eruptions at the Kerguelen Islands because they occur as far from the assumed eruption center as the deepest Kerguelen site, Site 745 in the Australian-Antarctic Basin. This period of numerous volcanic eruptions is also documented in the increased concentrations of glass shards within dispersed ash layers studied from Site 747 (Fig. 2 and Table 1). The Miocene tephras from Sites 737 and 747 may be correlated because most of them occur at the same time and they belong to the same trachytic group. However, Ash Layers 80 and 81-1 display higher silica and lower alkali contents than those from Site 747 (86-2 and 48). The transitional-basaltic upper Oligocene tephra layers from Site 737 (81-2 and 82) and Site 747 ( 25 and 26) are chemically identical and occur in the same time period, suggesting the same eruptive events. The Kerguelen Islands are assumed to be the source region for these ashes, as both sites are within the major wind and ocean current directions from those islands. Trachytic to rhyolitic glasses from Ash Layers 25 and 26 were not found at Site 737 and are absent either because of a hiatus or the lack of recovery during drilling. Alternatively, Heard Island could be the source because of their closer geographic position. The early Oligocene transitional-basaltic ashes from Site 737 were found in the dispersed glasses at Site 747B (e.g., 158-1). Higher glass concentrations not investigated here occur at that site in the lower Oligocene and may correspond to alkalibasaltic Ash Layers 84-1 and 84-2 from Site 737.

\section{CONCLUSIONS}

The volcanic ash layers studied from the Leg 120 sites belong to two different rock series: a basaltic series and a trachytic one. The tephras of basaltic composition occur predominantly in the Oligocene sediments; only one basaltic ash layer was found in the Quaternary. The Miocene, Pliocene, and most of the Quaternary tephras belong to a trachytic group. When compared with the volcanic products of the Kerguelen Islands, it is obvious that most of the tephras were formed through eruptive events at that locality. A less important contribution from Heard, Crozet, or other islands has to be considered for some of the tephras. At least five distinct eruptive events can be detected in more than one of the Leg 119 and 120 Kerguelen Plateau sites: (1) a Quaternary trachytic tephra correlated between Site 736 and 747A; (2) a Quaternary basaltic tephra encountered at Sites 736 and 749; (3) low-K calc-alkaline volcanic ash in Quaternary sediments, probably derived from the South Sandwich island arc by sea-ice rafting; (4) several Pliocene and Miocene trachytic tephras that are distributed over the entire Kerguelen Plateau and are deposited as far as the Antarctic-Australian Basin (Site 745); and (5) late and early Oligocene basaltic tephra layers occurring at Sites 737 and 747 . The correlation of distinct tephra layers between different sites on the Kerguelen Plateau area may be regarded as a first step toward a tephrostratigraphy of the polar Indian Ocean. Future investigations on characteristic trace elements and on glass populations of smaller grain size within dispersed ash concentrations will be needed to establish this tephrostratigraphy.

\section{ACKNOWLEDGMENTS}

We wish to thank Heike Ostermann (AWI) and Erika Lutz (Freiburg University) for technical help and assistance during sample processing and microprobe measurements. Financial support by the Deutsche Forschungsgemeinschaft (Grants Fu $119 / 14$ and $\mathrm{Hu}$ 378/2) is acknowledged. This is AWI Publication No. 346 .

\section{REFERENCES}

Baker, P. E., 1978. The South Sandwich Islands: III. Petrology of the volcanic rocks. Sci. Rept. Br. Antarct. Surv., 93.

Barron, J., Larsen, B., et al., 1989. Proc. ODP, Init. Repts., 119: College Station, TX (Ocean Drilling Program).

Chevallier, L., Nougier, J., and Cantagrel, J. M., 1983. Volcanology of Possession Island, Crozet Archipelago (TAAF). In Oliver, R. L., James, P. R., and Jago, J. B. (Eds.), Antarctic Earth Science: Cambridge (Cambridge Univ. Press), 652-658.

Clarke, I., McDougall, I., and Whitford, D. J., 1983. Volcanic evolution of Heard and McDonald Islands, southern Indian Ocean. In Oliver, R. L., James, P. R., and Jago, J. B. (Eds.), Antarctic Earth Science: Cambridge (Cambridge Univ. Press), 631-635.

Dietrich, G., and Ulrich, J., 1968. Atlas zur Ozeanographie: Mannheim (Bibliographisches Institut).

Fisher, R. L., Jantsch, M. Z., and Comer, R. L., 1982. General Bathymetric Chart of the Oceans (GEBCO), Scale 1:10,000.000. 5-9: Ottawa (Canadian Hydrographic Service).

Giret, A., and Lameyre, J., 1983. A study of Kerguelen plutonism: petrology, geochronology and geological implications. In Oliver, R. L., James, P. R., and Jago, J. B. (Eds.), Antarctic Earth Science: Cambridge (Cambridge Univ. Press), 646-651.

Giret, A., Lameyre, J., Beaux, J.-F., Gautier, I., Verdier, O., Chotin, P., and Cantagrel, J.-M., 1987. Géologie, deux siècles de recherche dans les iles Kerguelen. Actes Colloq. Rech. Fr. Terres Australes, 345-355.

Girod, M., and Nougier, J., 1972. Volcanism of the Sub-antarctic islands. In Adie, R. J. (Ed.), Antarctic Geology and Geophysics: Oslo (Universitetsforlaget), 777-789.

Gunn, B. M., Abranson, E. C., Watkins, N. D., and Nougier, J., 1972. Petrology and geochemistry of Iles Crozet: a summary. In Adie, R. J. (Ed.), Antarctic Geology and Geophysics: Oslo (Universitetsforlaget), 825-829.

Hayes, D. E., and Vogel, M., 1981. General Bathymetric Chart of the Oceans (GEBCO), Scale 1:10,000.000. 5-13: Ottawa (Canadian Hydrographic Service).

Houtz, R. E., Hayes, D. E., and Markl, R. G., 1977. Kerguelen Plateau bathymetry, sediment distribution and crustal structure. Mar. Geol., 25:95-130.

Hubberten, H.-W., Morche, W., Westall, F., Fütterer, D. K., and Keller, J., 1991. Geochemical investigations of volcanic ash layers from southern Atlantic Legs 113 and 114. In Ciesielski, P. F., 
Kristoffersen, Y., et al., Proc. ODP, Sci. Results, 114: College Station, TX (Ocean Drilling Program), 733-749.

Jarosewich, E., Nelen, J. A., and Norberg, J. A., 1980. Reference samples for electron microprobe analysis. Geostandards Newslett., 4:43-47.

MacDonald, G. A., and Katsura, T., 1964. Chemical composition of Hawaiian lavas. J. Petrol., 5:82-133.

Morche, W., Hubberten, H.-W., Ehrmann, W. U., and Keller, J., 1991. Geochemical investigations of volcanic ash layers from Leg 119 to Kerguelen Plateau. In Barron, J., Larsen, B., et al., Proc. ODP, Sci. Results, 119: College Station, TX (Ocean Drilling Program).

1972a. Geochronology of the volcanic activity in Iles Kerguelen. In Adie, R. J. (Ed.), Antarctic Geology and Geophysics: Oslo (Universitetsforlaget), 803-808.

1972b. Volcanic associations in Iles Kerguelen. In Adie, R. J. (Ed.), Antarctic Geology and Geophysics: Oslo (Universitetsforlaget), 809-815.

Nougier, J., Pawlowski, D., and Cantagrel, J. M., 1983. Chronospatial evolution of the volcanic activity in southeastern Kerguelen (T.A.A.F.). In Oliver, R. L., James, P. R., and Jago, J. B. (Eds.), Antarctic Earth Science: Cambridge (Cambridge Univ. Press), 640-645.
Schlich, R., 1975. Structure et age de l'océan Indien occidental. Mem. Hors-Ser. Soc. Geol. Fr., 6:1-103.

Schlich, R., Wise, S. W., Jr., 1989. Proc. ODP, Init. Repts., 120: College Station, TX (Ocean Drilling Program).

Stephenson, P. J., 1972. Geochemistry of some Heard Island igneous rocks. In Adie, R. J. (Ed.), Antarctic Geology and Geophysics: Oslo (Universitetsforlaget), 793-801.

Taylor, S. R., Arculus, R., Perfit, M. R., and Johnson, R. W., 1981. Island arc basalts. Basaltic Volcanism on the Terrestrial Planets. Basaltic Volcanism Study Project: New York (Pergamon Press), 193-213.

Watkins, N. D., Gunn, B. M., Nougier, J., and Baksi, A. K., 1974. Kerguelen: continental fragment or oceanic island? Geol. Soc. Am. Bull., 85:201-212.

Whitworth, T., III, 1988. The Antarctic circumpolar current. Oceanus, 31:53-58.

Date of initial receipt: 16 January 1989

Date of acceptance: 22 October 1990

Ms 120B-163

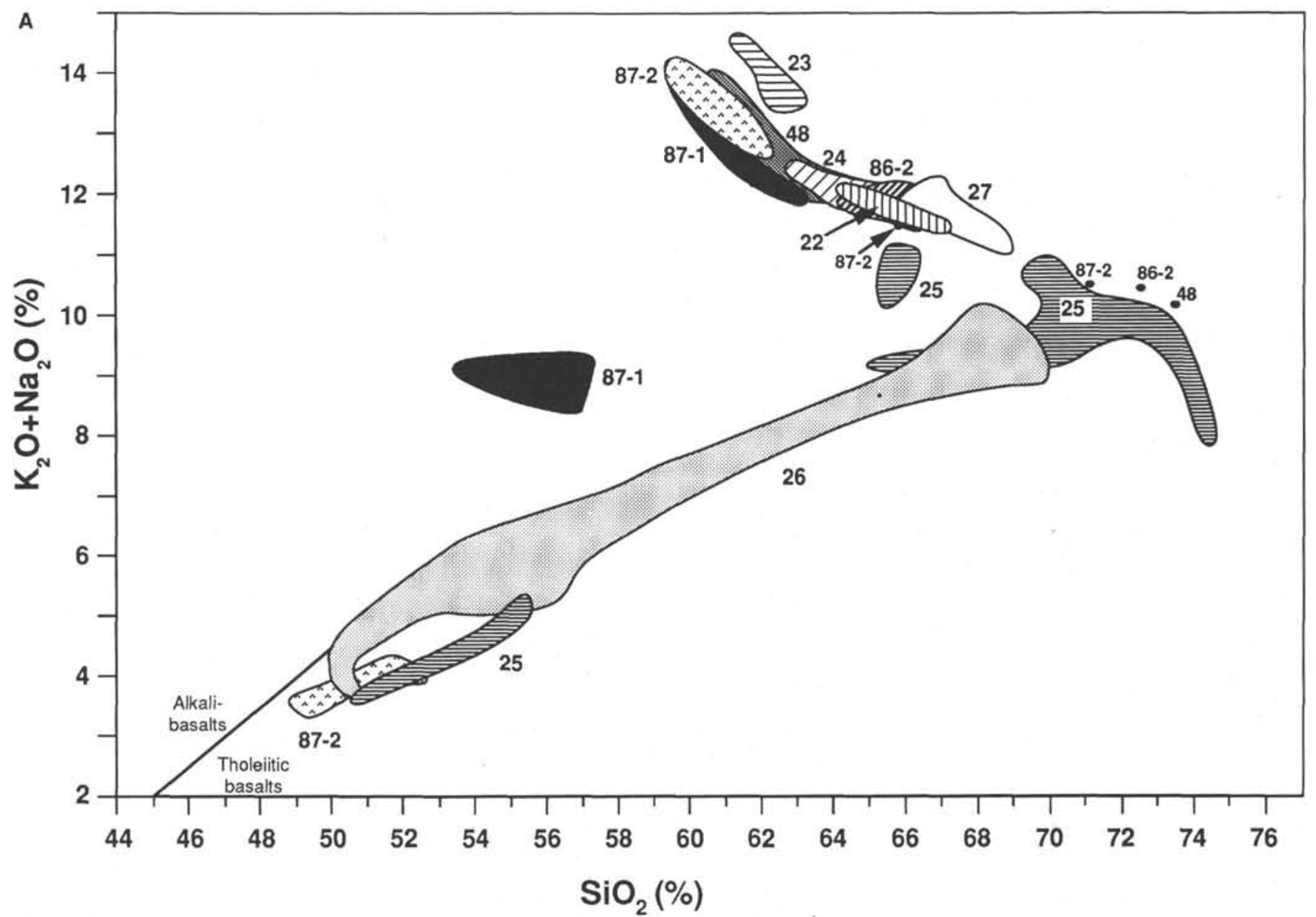

Figure 3. Total alkali vs. silica diagrams for discrete ash layers (A) and accumulations of dispersed ash layers (B) investigated in this study. Numbers given in the diagram correspond to the AWI sample numbers. The discriminating line between the alkali and tholeiitic basalts has been plotted according to MacDonald and Katsura (1964). Fields of discrete ash layers are shown in black for comparison in Figure 3B. 


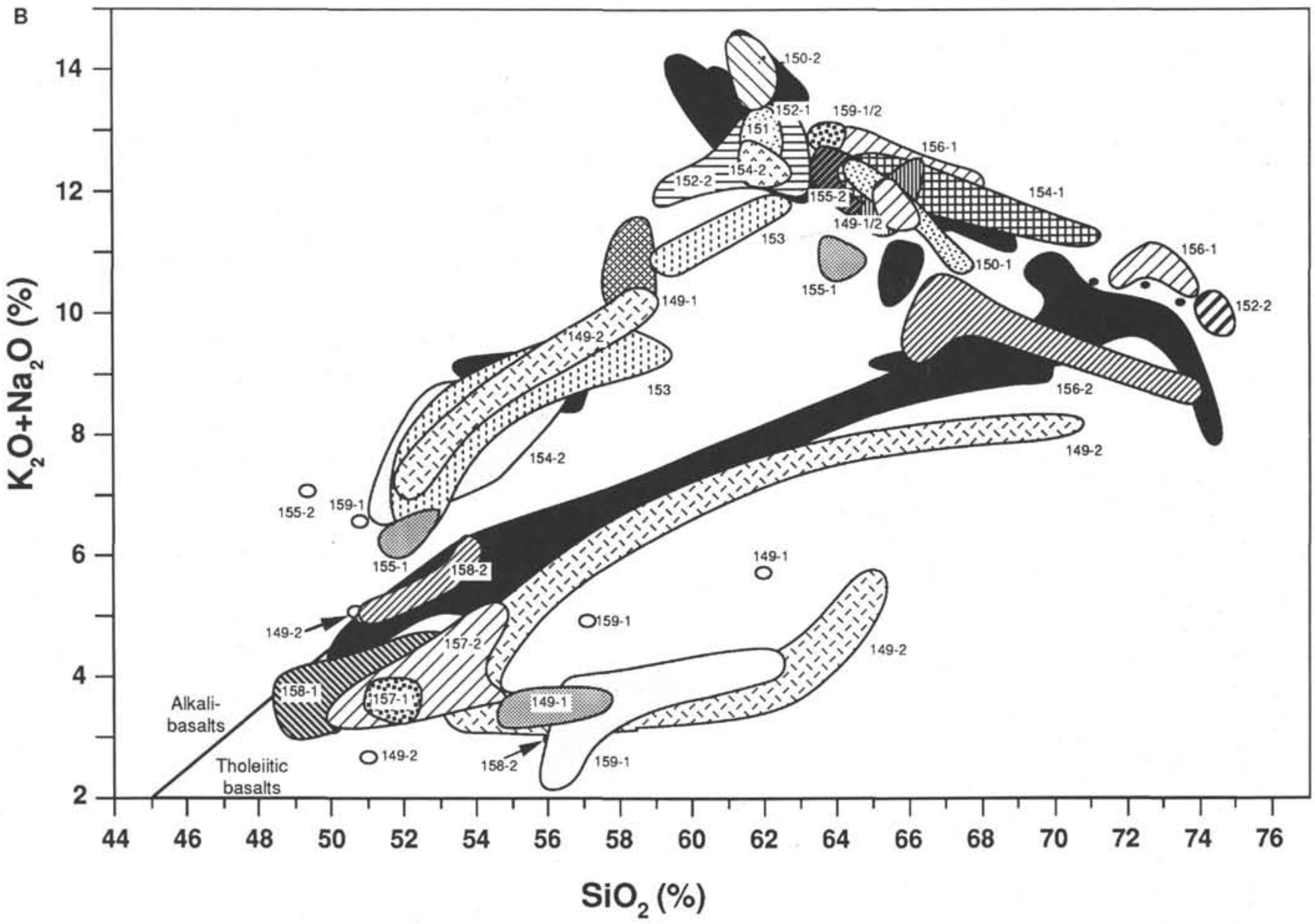

Figure 3 (continued).

Table 5. Average composition of all Leg 119 and 120 calc-alkaline tephras.

\begin{tabular}{|c|c|c|c|c|c|c|c|c|c|c|}
\hline & (\%) & $\mathrm{SiO}_{2}$ & $\mathrm{TiO}_{2}$ & $\mathrm{Al}_{2} \mathrm{O}_{3}$ & $\mathrm{FeO}$ & $\mathrm{MnO}$ & $\mathrm{MgO}$ & $\mathrm{CaO}$ & $\mathrm{K}_{2} \mathrm{O}$ & $\mathrm{Na}_{2} \mathrm{O}$ \\
\hline Leg 120 & Mean & 57.75 & 1.10 & 15.41 & 10.48 & 0.22 & 3.20 & 7.92 & 0.58 & 3.34 \\
\hline$N=15$ & SD & 3.43 & 0.32 & 1.52 & 2.57 & 0.07 & 1.47 & 1.26 & 0.14 & 0.91 \\
\hline${ }^{a}$ Leg 119 & Mean & 56.87 & 1.12 & 15.40 & 10.96 & 0.20 & 3.25 & 8.49 & 0.58 & 3.03 \\
\hline$N=24$ & SD & 2.90 & 0.21 & 0.98 & 1.40 & 0.11 & 1.46 & 1.28 & 0.18 & 0.54 \\
\hline${ }^{\mathrm{b}}$ South Sandwich Islands & Mean & 55.50 & 1.00 & 16.13 & 10.96 & 0.19 & 3.85 & 8.70 & 0.55 & 3.00 \\
\hline$N=15$ & SD & 2.95 & 0.28 & 1.37 & 1.48 & 0.03 & 1.37 & 1.53 & 0.26 & 0.44 \\
\hline${ }^{c}$ Leg 114 & Mean & 56.64 & 1.09 & 15.56 & 11.17 & 0.25 & 3.41 & 8.27 & 0.36 & 3.20 \\
\hline$N=15$ & SD & 0.79 & 0.10 & 0.41 & 0.62 & 0.09 & 0.43 & 0.25 & 0.06 & 0.32 \\
\hline
\end{tabular}

Notes: Tephras are from low-K series and are shown in comparison with South Sandwich Islands volcanic rocks and the Quaternary Leg 114 Tephra 114-701A-1H-4, 58-60 cm.

${ }^{\text {a }}$ Morche et al. (1991).

b Baker (1978).

${ }^{c}$ Hubberten et al. (1990). 

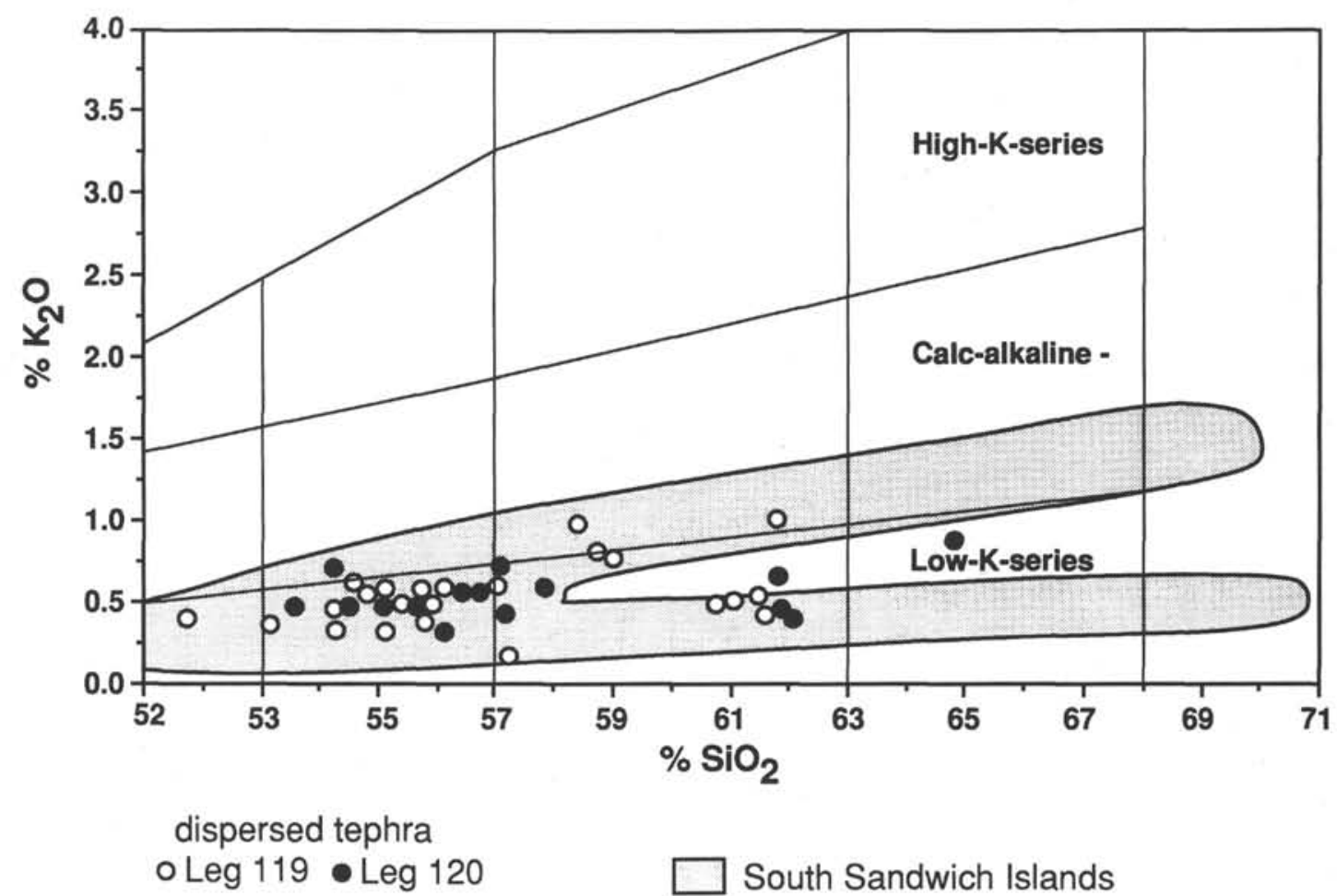

\section{South Sandwich Islands}

Figure 4. Comparison of dispersed glasses from Legs 119 and 120 with the probable source area of the South Sandwich Islands in the $\mathrm{K}_{2} \mathrm{O}-\mathrm{SiO}_{2}$ diagram. Classifications are after Taylor et al. (1981); data are from Baker (1978) and Morche et al. (1991).
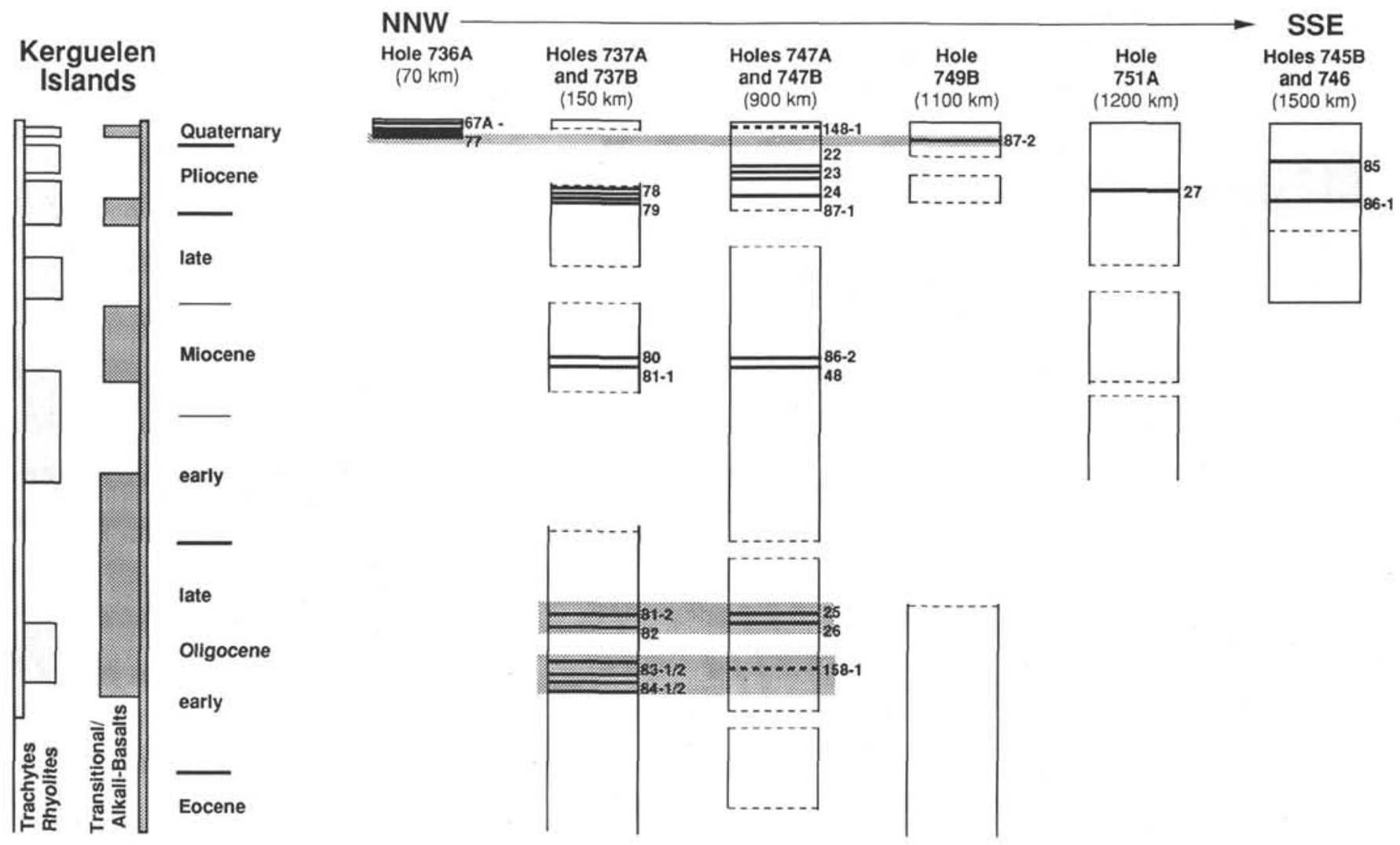

Figure 5. Geochronological synthesis of discrete tephra layers from Legs 119 and 120 compared with dated rock series from the Kerguelen Islands. The time scale for the Kerguelen Islands shows dated volcanic/intrusive activity (data from Nougier, 1972a, and Giret et al., 1987). Distances from the holes to the Kerguelen Islands are indicated in parentheses. 